\title{
PEEPS S-STEM Partnering with Americorps CSU STEM VISTAs
}

\section{Dr. Lizabeth T. Schlemer, California Polytechnic State University, San Luis Obispo}

Lizabeth is an Associate Dean and a professor at Cal Poly, SLO in Industrial and Manufacturing Engineering. In her current role so advocates for access and equity for undergraduates at the university. She has been teaching for 25 years and has continued to develop innovative pedagogy such as project based, flipped classroom and competency grading. Through the SUSTAIN SLO learning initiative she and her colleagues have been active researching in transformation in higher education.

\section{Dr. Jane L. Lehr, California Polytechnic State University, San Luis Obispo}

Jane Lehr is Chair of the Women's \& Gender Studies Department and Professor in Ethnic Studies at California Polytechnic State University, San Luis Obispo. She is also Faculty Director of the Cal Poly Louis Stokes Alliance for Minority and Underrepresented Student Participation in STEM Program. She previously served as elected co-chair of the Science \& Technology Taskforce of the National Women's Studies Association, and as a Postdoctoral Research Officer at the Centre for Informal Learning and Schools (CILS) at King's College, University of London. Her graduate training is in Science \& Technology Studies and Women's Studies at Virginia Tech.

\section{Ms. Emily E. Liptow, California Polytechnic State University, San Luis Obispo}

Emily Liptow currently works at a tech startup accelerator in Cleveland $\mathrm{OH}$ where she manages a coworking space and promotes community and diversity in the city's entrepreneurship ecosystem. She served as an AmeriCorps VISTA member at California Polytechnic State University in San Luis Obispo where she was involved with a variety of diversity and inclusion efforts in the College of Engineering ranging from student support programs, faculty bias awareness trainings, and inclusive cultural change. Prior to her work at Cal Poly, received a B.S. in Industrial and Systems Engineering from Ohio State University, where she was also very involved with social justice initiatives.

\section{Miss Monica Lauren Singer, AmeriCorps VISTA}

Monica Singer is an AmeriCorps VISTA (Volunteer in Service to America) supporting diversity and inclusion initiatives within the college of engineering at California Polytechnic State University, San Luis Obispo. There she received her Bachelor's degree in Psychology with minors in Gender, Race, Culture, Science \& Technology and Child Development. She is currently a research assistant in the Advancing Cultural Change lab on campus studying students' lived experiences with a focus on STEM disciplines. Her research interests include masculinity and implicit bias in academia (specifically in the STEM fields).

\section{Dr. Katherine Chen, Worcester Polytechnic Institute}

Dr. Katherine C. Chen is the Executive Director of the STEM Education Center at Worcester Polytechnic Institute (WPI). Her degrees in Materials Science and Engineering are from Michigan State University and MIT. Her research interests include pre-college engineering education and equity in education. 


\section{PEEPS S-STEM Partnering with AmeriCorps CSU STEM VISTAs}

We are in the 4th year of a 5 year NSF S-STEM grant called PEEPS (Program for Engineering Excellence for Partner Schools). The scholarship program was designed to support students from high schools that are under-resourced, "Partner Schools," to obtain an undergraduate engineering degree at California Polytechnic State University, San Luis Obispo. Students receive up to $\$ 10,000 /$ year in financial aid. The program was modeled after the Posse Foundation Scholarship program. At our university, students formed a cohort being scheduled into engineering major and support courses together during their first two years. Students also engaged in monthly advising sessions, tutoring services, engineering success courses, group socials and engineering outreach activities. Currently, we are aiding students in developing professional mentorships to aid in career choices.

Throughout the grant, we have had an AmeriCorps CSU STEM VISTA members supporting the effort in a variety of ways. There have been three different VISTAs and each has brought a strength to the program. VISTA members coordinated social events and academic tutoring. They mentored and helped students maneuver the university system. The VISTAs are supported through the California State University's Chancellors Office. This paper will outline the logistics and mechanism for the involvement of the VISTA members and their individual contributions to the NSF Grant effort.

We strongly believe other grantees should investigate the availability of this rich and diverse community of volunteers as we believe the current S-STEM grant was very much enhanced by their ongoing participation

\section{Introduction}

This paper and poster will describe the S-STEM PEEPS and the CSU STEM VISTA partnership. The S-STEM grant has engaged VISTA volunteers to support the goals of the program. We believe the VISTA program can be a source of institutional support to NSF grantees and we urge others to investigate these opportunities in their own state or institutional systems.

\section{S-STEM PEEPS}

PEEPS is an S-STEM scholarship and support program at California Polytechnic State University, San Luis Obispo. The aim of the program is to support students from underresourced backgrounds in as many ways as possible to help them complete engineering degrees. The 13 students in the program receive up to $\$ 10,000$ per year of financial scholarships and a wide range of other support throughout their time at Cal Poly. We designed the cohorts around the Posses Foundation Scholarship program [1]. Initially, we helped to build the cohesiveness of the cohort by scheduling students into math, science and major course together and creating social activities. We have written several papers for ASEE national conferences describing the results of our experiment $[2,3,4]$. We are just finishing the 4 th year with several students completing their degrees. In addition, there are two students who have left the university. The results from the perspective of institutional measures of success are mixed, but the students who 
are participating indicate the PEEPS program has been a huge source of support for them. We will continue to follow these students and report on results as we complete the project.

\section{AmeriCorps VISTA}

THE CSU STEM VISTA is part of a larger federal volunteer organization that began in 1965. The VISTA (Volunteers in Service to America) program has had over 220,000 members serving in all 50 stated over the last 50 years. "The AmeriCorps VISTA mission is to strengthen organizations that alleviate poverty through volunteering and the mobilization of resources." [5]

VISTA was conceived by President John F. Kennedy as a domestic version of the Peace Corps and was later initiated by President Lyndon Johnson as part of the War on Poverty. The first VISTAs served in migrant farm camps in California, towns in rural Kentucky, and the urban areas of Hartford Connecticut. AmeriCorps and VISTA merged in 1994 and is now part of the Corporation for National and Community Service (www.nationalservice.gov). The organization has been growing in impact and numbers.

There are five main service areas: Disaster Services, Economic Opportunity, Education, Healthy Futures, and Veterans and Military Families. There are also specific initiatives like the STEM VISTA that was started by President Obama in 2009 by launching "Educate to Innovate" which aimed to educate American students for careers in STEM workforce. Later, in 2013, the STEM AmeriCorps was launched to specifically place volunteers in nonprofits across the country to inspire young people to excel in STEM.

"The goals of STEM AmeriCorps are to:

- Improve academic performance and engagement in STEM coursework for K-12 students

- Increase the number of students on track to graduate ready for college and for careers in STEM fields, including those populations who typically participate at lower rates

- Spark the imagination and interest of students to pursue STEM careers [6]"

The California State University (CSU) participates in this national endeavor by coordinating the program through the Chancellors Office (CO). The specific aim of the CSU program is "to mobilize the university to inspire traditionally underrepresented students (students of color, lowincome, first-generation, and women) to complete degrees in STEM fields." [7] The CSU goal is also supported by the California Graduation Initiative 2025 [8] that aims to increase graduation rates for all students and to close the achievement gap for underrepresented minority students.

During the 2016-17 academic year, the CSU placed 19 Volunteers at 10 campuses throughout the CSU. The volunteers worked on a variety of projects from creating food pantries to supporting undocumented students. At our university, we have had multiple VISTAs each year for the last 4 years. Each year there was one volunteer that supported our S-STEM PEEPS work. 


\section{Logistic Details of CSU STEM VISTA}

Below we describe the logistic details for the CSU STEM VISTA that is coordinated through the $\mathrm{CO}$ of the CSU. We will describe the application process, the financial aspects, and the resources needed once the VISTA comes to campus. There are multiple organizations in each state that coordinate AmeriCorps VISTAs that provide similar support.

\section{Application Process}

In November, the CO posts a Request for Proposal (RFP). For the last several years the RFP has used the Anti-Deficit Achievement Framework [9] and thus the proposals are written with this framework in mind. The proposal process is not onerous, but it does require a complete conceptualization of the work the volunteers will be doing along with the financial and institutional commitments.

The proposals are usually due at the beginning of February with a complete signoff by the intuitions. At our university, this logistic and budget approval work takes some time and we need to complete our proposals by mid-January.

We are notified of the acceptance of the proposal in March.

In April, we are able to review the application for specific volunteers for selection to our site. Selection and placement are complete by mid-May.

The VISTA arrives on campus on July 1, but there is much organization that is required by the supervisors before this date. The CO works with the supervisor to develop an onboarding plan and works to ensure the volunteer has workspace and computers along with the necessary access to campus resources.

In August, there is a mandatory three-day training for VISTA and supervisors that we found very valuable.

The reporting and supervising relationship is one that is worked out between the VISTA and the Supervisor, but the $\mathrm{CO}$ does get involved if the relationships need intervention. The supervisory role can be as hands-off as a weekly check-in or as constant as working together in the same office.

The CO provides excellent ongoing career development for the VISTAS. They attend four 3-day retreats throughout the year, have monthly webinars, and periodic check-ins with the $\mathrm{CO}$. There are also requirements for reporting each quarter on people served and activities accomplished.

\section{Financial Aspects}

The Chancellors Office charges the sites a fee for the services they provide for coordinating the VISTA. The VISTAs receive a stipend from the federal government and in addition, we, at Cal Poly, optionally provide a monthly stipend to cover the high housing cost in San Luis Obispo. 
During three of the years, the VISTAs reported to faculty members who were also provided with assigned time of 1 Weighted Teaching Unit (WTU) per quarter. This assigned time was paid for by the College of Engineering dean. The justification for this time is that there is a workload beyond the normal duties of a faculty member including some time during the summer. This small release recognizes the faculty's time commitment. The total cost to the site varies with the number of years of involvement. Below are the itemized costs:

Site fees: $\$ 4000$ for the first year and $\$ 7000$ for a 4 th year position Housing Stipend: $\$ 9000$

Total cost for a Volunteer: $\$ 13,000$ to $\$ 16,000$

Assigned Time for Supervisor: \$6000/year

\section{On-Site Logistics}

In addition, the site must provide a space to work. This can be a shared space. In fact, at Cal Poly, the four VISTAs share a $100 \mathrm{sq} \mathrm{ft}$ office. The VISTA volunteer also needs a computer and access to campus. Access is usually provided through the affiliates designation.

\section{Specific contributions to the S-STEM PEEPS grant}

The VISTAs work 40 hours per week with approximately 10 days of mandatory training from the Chancellors office and 15 days of vacation/personal time. Per the RFP from the CO, the "VISTA projects must focus on building capacity and long-term sustainable solutions. This means that VISTA projects are prohibited from providing direct services (tutoring, mentoring, and/or teaching students directly). Instead, VISTA projects should leverage resources, expand the scale and reach, efficiency, and/or effectiveness of STEM student success efforts to eliminate the equity gap. These capacity building activities (i.e., indirect services) include things such as conducting a student needs assessment, building infrastructure, expanding partnerships, and securing long-term resources." [10]

Over the four years of this S-STEM PEEPS grant, we have had three separate VISTA volunteers. They were all recent college graduates. Each brought a different set of strengths to the program. Our initial proposal was to have this person help to expand our connection with the Partner schools and to support the PEEPS scholars.

The first VISTA was a man of color who was an engineer and graduate from Cal Poly. He connected with the PEEPS very well. During the first year, we all were trying to figure out how to support the grant activity and to support the students. He did an exceptional job in developing policies and procedures. He was involved in tracking the students, organizing social events, and meeting with students monthly. He also helped to coordinate institutional activities like meetings with the support team of faculty and staff.

The second two years the VISTA was a woman engineer from the Midwest. She was very supportive of the PEEPS, getting to know them and connecting on a personal level. Because she was here for two years, she was able to expand the work to include social justice issues with 
campus partners while maintaining the support necessary for the PEEPS students. Her activities connected the PEEPS work with other organization on campus including the undocumented students, the EPIC summer camp, and social science research group looking at gender issues in engineering.

The VISTA this year is a woman who graduated from Cal Poly with a Psychology degree. She has brought a unique perspective that has once again shaped our work. The PEEPS students are in their 3rd and 4th year and the work necessary is not as extensive so she is much more involved in developing new initiatives on campus. She has been working with the Women's Engineering Program (WEP) on building capacity for the university to apply for an NSF ADVANCE grant. She has also worked extensively with the Advancing Cultural Change (ACC) lab that is examining gender and minority issues in engineering.

This experience enriches us all. The support team has been influenced by the VISTA volunteers and the volunteers have learned in the process. Below is a quote from one of our volunteers as she reflects on her time at Cal Poly, SLO.

"I serve because apathy to issues of racism, poverty, sexism, transphobia, and xenophobia perpetuates them. I serve to fight for everyone's right to pursue an education. I serve to empower the most vulnerable communities in our country. I serve because the fight for justice never ends." [11].

\section{Conclusion}

The connection between the S-STEM PEEPS grant and the CSU STEM AmeriCorps VISTA has been mutually beneficial. The volunteers who participated contributed to the PEEPS program and the VISTAs themselves also benefits by learning about higher education and their own passions in a deep way.

We urge other grantees to explore the possibilities at your site for this amazing resource that helps to shape the future of the work we do.

\section{Acknowledgements}

This work was supported by a grant from the National Science Foundation, S-STEM grant $\# 1356753$. All opinions expressed are those of the authors and not necessarily those of the National Science Foundation.

\section{References}

[1] Jones, S.A. and Were, M. "Impact of the POSSE Program on the Academic Integration of Minority Engineering Students." ASEE/IEEE Frontiers in Education Conference. Saratoga Springs, NY, October 22-25, 2008

[2] Chen, K. C., \& Schlemer, L. T., \& Lehr, J. L., \& Liptow, E. E., \& Duerr, J., \& Finger, H., \& Cabanez, J. B., "PEEPS: Cultivating a Cohort of Supportive Engineering Students and Building 
a Support Team for Institutional Change," Paper presented at 2016 ASEE Annual Conference \& Exposition, New Orleans, Louisiana, 2016

[3] Chen, K., \& Schlemer, L. T., \& Liptow, E. E., \& Duerr, J., \& Finger, H., \& Lehr, J. L. "I get by with a little help from my PEEPS: Learning from an NSF S-STEM cohort scholarship program", Paper presented at 2017 ASEE Annual Conference \& Exposition, Columbus, Ohio. June 2017

[4] Liptow, E. E., \& Chen, K., \& Parent, R., \& Duerr, J., \& Henson, D., “A Sense of Belonging: Creating a Community for First-generation, Underrepresented groups and Minorities through an Engineering Student Success Course", Paper presented at 2016 ASEE Annual Conference \& Exposition, New Orleans, Louisiana. June 2016.

[5] https:/www.nationalservice.gov/programs/americorps/americorpsvista/about-americorpsvista)

[6] https://www.nationalservice.gov/special-initiatives/task-force-expanding-nationalservice/stem-americorps

[7] http://www.calstate.edu/cce/vista/

[8] https://www2.calstate.edu/csu-system/why-the-csu-matters/graduation-initiative-2025

[9] Harper, S. R. "An anti-deficit achievement framework for research on students of color in STEM.” In S. R. Harper \& C. B. Newman (Eds.), Students of color in STEM: Engineering a new research agenda. New Directions for Institutional Research San Francisco: Jossey-Bass. 2010, pp. 63-74.

[10] http://www.calstate.edu/cce/vista/host-vista/documents/2018-19-VISTA-(RFP).pdf

[11] https://csustemvista.wordpress.com/ 